\title{
Kolbe Electrolysis for the Conversion of Carboxylic Acids to Valuable Products-A Process Design Study
}

\author{
Daniel Klüh *D, Wolfgang Waldmüller (D) and Matthias Gaderer \\ Regenerative Energy Systems, Campus Straubing for Biotechnology and Sustainability, \\ Technical University of Munich, Schulgasse 16, 94315 Straubing, Germany; \\ wolfgang.waldmueller@tum.de (W.W.); gaderer@tum.de (M.G.) \\ * Correspondence: daniel.klueh@tum.de; Tel.: +49-9421-187-128
}

Citation: Klüh, D.; Waldmüller, W.; Gaderer, M. Kolbe Electrolysis for the Conversion of Carboxylic Acids to Valuable Products-A Process Design Study. Clean Technol. 2021, 3, 1-18. https://doi.org/10.3390/cleantechnol 3010001

Received: 17 November 2020 Accepted: 15 December 2020 Published: 2 January 2021

Publisher's Note: MDPI stays neutral with regard to jurisdictional clai$\mathrm{ms}$ in published maps and institutional affiliations.

Copyright: (C) 2021 by the authors. Licensee MDPI, Basel, Switzerland. This article is an open access article distributed under the terms and conditions of the Creative Commons Attribution (CC BY) license (https:// creativecommons.org/licenses/by/ $4.0 /)$.

\begin{abstract}
The substitution of fossil resources by renewable alternatives is a major challenge for our society. Kolbe electrolysis converts carboxylic acids to hydrocarbons, which can be used as base chemicals, specialty chemicals, or fuels. Carboxylic acids may be retrieved from biomass or residues and, in consequence, can be a sustainable feedstock. Since the Kolbe electrolysis has only been investigated in lab scale, this work proposes the first basic engineering design study on process development for a continuously working process. Thermophysical data, including solubility and boiling point, are used to gain insight into requirements on process equipment such as separation processes or process parameters such as operating temperature. Furthermore, Aspen Plus was used to retrieve information on acid base equilibria and azeotropes. The process development for three different feedstocks (acetic acid, valeric acid and lauric acid) was performed. The process design shows that most of the process units are rather straightforward and rely on state of the art technologies. The addition of an alkaline catalyst improves the solubility and deprotonation of the carboxylic acid but on the cost of a possibly lower product selectivity. Elevation of the operating temperature above the Krafft point is necessary for long-chain fatty acids. Kolbe electrolysis can be an interesting technology for future production processes based on carboxylic acids and electricity from sustainable sources.
\end{abstract}

Keywords: process development; Kolbe electrolysis; electrochemical process; renewable chemicals; fatty acids; solubility; carboxylic acid; process flow diagram; Power-to-Chemicals

\section{Introduction}

Climate change is an inherent problem that the world is facing [1]. The use of renewable energies in the electricity sector is capable of reducing $\mathrm{CO}_{2}$ emissions significantly compared to electricity generation based on fossil fuels. Therefore, the extension of renewable energy capacities is ongoing worldwide. For example, in Germany, renewable energy generation capacity accounted for $57 \%$ of the total electricity production capacity in the year 2018 [2]. In the same year, 40\% of Germany's electricity production stemmed from renewable sources [3]. A high share of renewable energies, namely fluctuating renewable energies such as wind and solar power, can cause major strains on the energy system. The fluctuating electricity generation calls for processes capable of utilizing electricity flexibly. Especially electrochemical processes offer a flexible power uptake. The water electrolysis towards hydrogen and oxygen might be the most prominent example as it is an essential part in the development of flexible Power-to-Gas and Power-to-Liquid process chains.

However, the flexible operation of electrolysis is also possible using organic feedstock. The Kolbe electrolysis, named after the German chemist Herrmann Kolbe, describes the electrochemical conversion of carboxylic acids to valuable products. Kolbe described the decomposition of valeric acid by an electric current [4]. He observed the evolution of hydrogen, carbon dioxide and an oleaginous liquid, which consisted of the main product octane and the side product butyl valerate. The Kolbe electrolysis is capable of connecting the 
utilization of electricity and biomass resources as feedstocks. Therefore, Kolbe electrolysis can be incorporated in biorefinery concepts [5]. The technology itself addresses a lot of the twelve principles of Green Chemistry and represents a green production process for future applications [6].

The first step of the reaction mechanism is the deprotonation of carboxylic acid ( $R$ $\mathrm{COOH})($ Equation (1)). At the anode, the deprotonated acid reacts further to a radical and carbon dioxide (Equation (2)). The Kolbe main product is the hydrocarbon dimer, which is produced by the combination of two radicals (Equation (3)). At the cathode, the evolution of hydrogen according to Equation (4) occurs.

$$
\begin{gathered}
\mathrm{R}-\mathrm{COOH} \rightarrow \mathrm{R}-\mathrm{COO}^{-}+\mathrm{H}^{+} \\
\mathrm{R}-\mathrm{COO}^{-} \rightarrow \mathrm{R}^{*}+\mathrm{CO}_{2}+\mathrm{e}^{-} \\
2 \mathrm{R}^{*} \rightarrow \mathrm{R}-\mathrm{R} \\
2 \mathrm{e}^{-}+2 \mathrm{H}^{+} \rightarrow \mathrm{H}_{2} \\
\mathrm{R}-\mathrm{COOH}+\mathrm{R}-\mathrm{OH} \rightleftharpoons \mathrm{R}-\mathrm{COO}^{*}+\mathrm{R}+\mathrm{H}_{2} \mathrm{O} \\
2 \mathrm{R}-\mathrm{COOH} \rightarrow \mathrm{R}-\mathrm{R}+\mathrm{H}_{2}+2 \mathrm{CO}_{2} \\
\mathrm{R}^{*}+\mathrm{H}^{*} \rightarrow \mathrm{R}-\mathrm{H}
\end{gathered}
$$

Side products such as alcohols (Equation (5)) and olefins (not shown) can be formed by former oxidation of the radical $[7,8]$. The alcohol tends to build ester with the carboxylic acid (Equation (6)). The overall reaction to the main product is depicted in Equation (7). Additionally, in aqueous solution, the electrolysis of water to hydrogen and oxygen is a possible side reaction. A high concentration of carboxylic feedstock, e.g., above $0.5 \mathrm{~mol} / \mathrm{L}$, favors the production of the Kolbe product [9] and suppresses water electrolysis [5]. Ahad and Klerk further assumed that adsorbed hydrogen radicals could react with the alkane radical as presented in Equation (8) [10].

Low temperature below $27^{\circ} \mathrm{C}$ and a neutral or slightly alkaline $\mathrm{pH}$ value support a higher selectivity towards the Kolbe product [9]. However, the $\mathrm{pH}$ value near the electrode is not necessarily the same as in the bulk of the liquid phase. Consumption of hydroxide ions and chemical dissolution of carbon dioxide can significantly lower the $\mathrm{pH}$ value near the electrode [8].

Multiple scientific investigations are already available on the topic of Kolbe electrolysis. An area of focus within the field is the production of biofuels. Dos Santos et al. investigated the conversion of fatty acids (FAs) and triglycerides to olefins and ethers [11]. Meyers et al. showed the production of diesel fuels via Kolbe electrolysis of 3-hydroxy-decanoic acid [12]. Holzhäuser et al. investigated the production of fuels from different kinds of feedstock [13]. Nilges et al. used Kolbe electrolysis as a step in the production of octane for the utilization as fuel [14]. Furthermore, coupling microbial production of carboxylic acids with Kolbe electrolysis to produce fuels was tested [15].

Another area of focus is the production of chemicals. De Kruijff and Waldvogel proposed the Kolbe electrolysis as a green production route for the production of methoxymethyl ethers [16]. Wu et al. showed the production of polymers and fuels based on levulinic acid [17]. Waxes can also be produced based on vegetable oil [18]. Calvin et al. presented a process design for renewable lubricant production. One process route involves the utilization of Kolbe electrolysis in order to convert oleic acid [19]. Stang and Harnisch investigated the Kolbe electrolysis of valeric acid [20]. A study on the utilization of Kolbe electrolysis for wastewater treatment was conducted on the wastewater of Fischer Tropsch processes containing acetic acid [10]. Furthermore, progress in cell design is ongoing. Recently, advances in the design of the electrochemical cells for Kolbe electrolysis were 
reported [21]. These examples show the broad variety of possible feedstocks and products that can appear in Kolbe electrolysis for the production of fuels and chemicals.

The mentioned studies were mainly conducted in lab-scale under mostly batch process conditions. Continuously working lab experiments have been performed and flow cells have been tested [21,22]. However, sufficient information for process development and upscaling of the technology is missing. Simulations, basic engineering studies of scale-up, economic assessment or pilot plant experiments are not available. The literature also states that there is a lack of process design and further development of the technology by assessing cost, life cycles and sustainability [23].

To close this knowledge gap, this work proposes the first analysis of challenges and issues in process development and suggests process designs for three different feedstocks. Consequently, it contributes to the further development of the technology to a continuously working process in a relevant size. This research aims at clarifying the thermophysical framework of the Kolbe electrolysis. Secondly, the paper presents a basic process design for the scale-up of selected processes. The properties of the products and feedstocks were retrieved from literature and the process design for the Kolbe electrolysis of three exemplary carboxylic acids was conducted.

\section{Methodology}

\subsection{Thermophysical Data Survey}

Several chemical and physical properties of the Kolbe feedstock and corresponding Kolbe products were retrieved from literature for thermophysical behavior. The homologous series of saturated linear FAs showing a carbon chain length $N$ from two to 18 carbon atoms were considered as feedstock. The corresponding main products (linear alkanes) with chain length $2 n-2$ were assessed.

The following parameters were investigated for their impact on the Kolbe electrolysis process design: melting and boiling point $\left(\mathrm{T}_{\text {melt }}, \mathrm{T}_{\text {boil }}\right)$ at ambient pressure, the water solubility at $25{ }^{\circ} \mathrm{C}$, the octanol/water partition coefficient at $25^{\circ} \mathrm{C}\left(\mathrm{K}_{\mathrm{OW}}\right)$, the acid dissociation constant (pKa) and the critical micelle concentration of longer FAs (CMC). Kolbe electrolysis of carboxylic acids works only if the acids are deprotonated. Thus, the characteristics of saponified FAs were investigated.

Data were mainly retrieved from the PubChem database and the property database of the free process simulation software ChemSep V8.01 [24,25]. Melting points of FAs with at least 8 carbon atoms were retrieved from Knother et al. [26]. Aqueous solubility of higher FAs $(C \geq 8)$ and all alkanes were estimated by the group contribution model I [27].

The phase behavior and chemical appearance of the feedstock and products of the Kolbe electrolysis were deduced from the retrieved data. This included the temperaturedepending prediction of the phase state, the dissociation of the FA, the aqueous solubility at alkaline conditions, and the formation of micelles.

\subsection{Process Development}

Three different potential feedstocks and corresponding products were further analyzed as scenarios concerning process development: acetic acid/ethane, n-valeric acid/octane, and lauric acid/docosane. The choice of carboxylic acids represents short, medium and long chain feedstocks. Retrieved thermophysical data from literature and additional data from Aspen Plus (Version 10, Aspentech, Boston, MA, USA) were used to decide on appropriate process steps. After the Kolbe electrolysis, a variety of different products are present in the stream. Process units such as separators, pressure changers and heat exchangers were considered for process development.

Every process stream was evaluated according to their composition. Based on the composition, the most appropriate process unit was chosen. The goal was to produce no waste streams and to reuse thermal energy as effectively as possible. 


\subsubsection{Evaluations in Aspen Plus}

Aspen Plus Version 10 was used to calculate binary vapor-liquid equilibrium diagrams and to determine the equilibrium constants of esterification. NRTL (Non-random-twoliquid model) was used as property method for both calculations. The NRTL activity coefficient model allows for the calculation of liquid-liquid and vapor-liquid equilibria of non-ideal mixtures. The activity coefficients were estimated using the modified UNIFAC (Dortmund) model (Universal quasichemical functional group activity coefficients) within the temperature range of the component's ambient boiling points.

The energetic balance of the chemical reactions to the Kolbe products and major side products was calculated based on Equation (9). $v_{i}$ and $v_{F A}$ are stoichiometric coefficients of the corresponding compounds and of the FA. $h_{F, i}^{0}$ is the standard enthalpy of formation of the corresponding compounds and were extracted from the Aspen Plus database. The reaction equations and and the values of $h_{F, i}^{0}$ are summarized in Table A1. Additionally, the enthalpy of combustion for each feedstock and main Kolbe product was calculated.

$$
\Delta h_{R}^{0}=\frac{1}{\left|v_{F A}\right|} \sum v_{i} \cdot h_{F, i}^{0}
$$

The mid-chain scenario valeric acid/n-octane produces butanol as side product, which reacts with the feedstock to ester and water in an equilibrium reaction. Its equilibrium constant $K$ is depicted in Equation (10). The values for the ester, water, alcohol, and acid refer to their respective molar concentrations. $K$ was calculated within the Aspen software using an isothermal RGibbs reactor. The RGibbs reactor determines the thermodynamic minimum of a reactive system and, thus, can be applied for the calculation of the equilibrial states.

$$
K=\frac{[\text { Ester }] \cdot[\text { Water }]}{[\text { Alcohol }] \cdot[\text { Acid }]}
$$

The process design further revealed that distillation is necessary to separate the ester butyl valerate from the product n-octane. For the detection of possible azeotropes of this separation, a T-xy-diagram of butyl valerate and n-octane was calculated at a pressure of 1 bar.

\subsubsection{Quantification of Process Efficiency}

For describing the Kolbe process efficiency, the maximum carbon efficiency, the Coulomb efficiency, the minimum gravimetric charge requirement and a theoretical energetic efficiency were calculated. These calculations all refer to the Kolbe main product; Side reactions are not considered.

The maximum carbon efficiency (CE) reports the ratio of carbon in the product based on the reactant's carbon content [28]. The carbon efficiency (in \%) is defined in Equation (11). $n_{C, i}$ refer to the molar amount of carbon atoms in the feedstock (FS) and the product (P). One can further represent the $\mathrm{CE}$ depending on the carbon chain length $\mathrm{N}$ in the feedstock when considering the Kolbe reaction stoichiometry.

$$
\mathrm{CE}=\frac{n_{C, P} \times 100}{n_{C, F S}}=\frac{2 \times \mathrm{N}-2}{2 \times \mathrm{N}} \times 100
$$

Due to inefficiencies and side reactions in the electrochemical system, the actually required charge for the formation of a product will always be higher than the theoretically calculated charge. The Coulomb efficiency $\eta_{C}$ is defined as the ratio between the theoretical charge required for the formation of a product to the actually required charge. $n_{t h, e}$ refers to the molar amount of theoretically required electrons for the reaction, i.e., one mol of transferred electrons per mole of converted molecules of the FA. $n_{\text {real }, e}$ describes the actual molar amount of electrons needed.

$$
\eta_{C}=\frac{n_{\text {th }, e} \times 100}{n_{\text {real }, e}}
$$


For the calculation of the minimum gravimetric charge requirement $Q_{\min }$ with the unit $\mathrm{C} / \mathrm{kg}$, a Coulomb efficiency of $100 \%$ was assumed. $z$ indicates the number of electrons transferred per reaction. For the calculations in this paper, $z$ equals two. $F$ is the Faraday constant. $M_{P}$ is the molar mass of the product.

$$
Q_{\min }=\frac{z \times F}{M_{P}}
$$

The maximum energetic efficiency $\eta_{e n, \max }$ was calculated by Equation (14). $h h v_{F A}$ is the molar higher heating value of the FA, $\Delta h_{R}^{0}($ Kolbe $)$ is the standard enthalpy of the Kolbe reaction, $E_{\min }$ is a minimum voltage of $2.5 \mathrm{~V}$, as given by Stang and Harnisch and $F$ is the Faraday constant [20]. The origin of the equation is described in Appendix B.

$$
\eta_{e n, \max }=\frac{h h v_{F A}+\Delta h_{R}^{0}(\text { Kolbe })}{h h v_{F A}+E_{\min } \times F}
$$

\section{Results}

\subsection{Properties of Pure Fatty Acids}

The melting and boiling points of pure FAs in protonated form and their corresponding Kolbe products are given in Figure 1. Small and medium-chain FAs up to nonanoic acid (C9) exhibit melting points below $25^{\circ} \mathrm{C}$. Longer FA chains resolve in an increase in the melting point up to $69.3^{\circ} \mathrm{C}$ for stearic acid (C18). FAs of odd carbon chain length show lower melting points than even FAs, while this effect mitigates with increasing chain length.
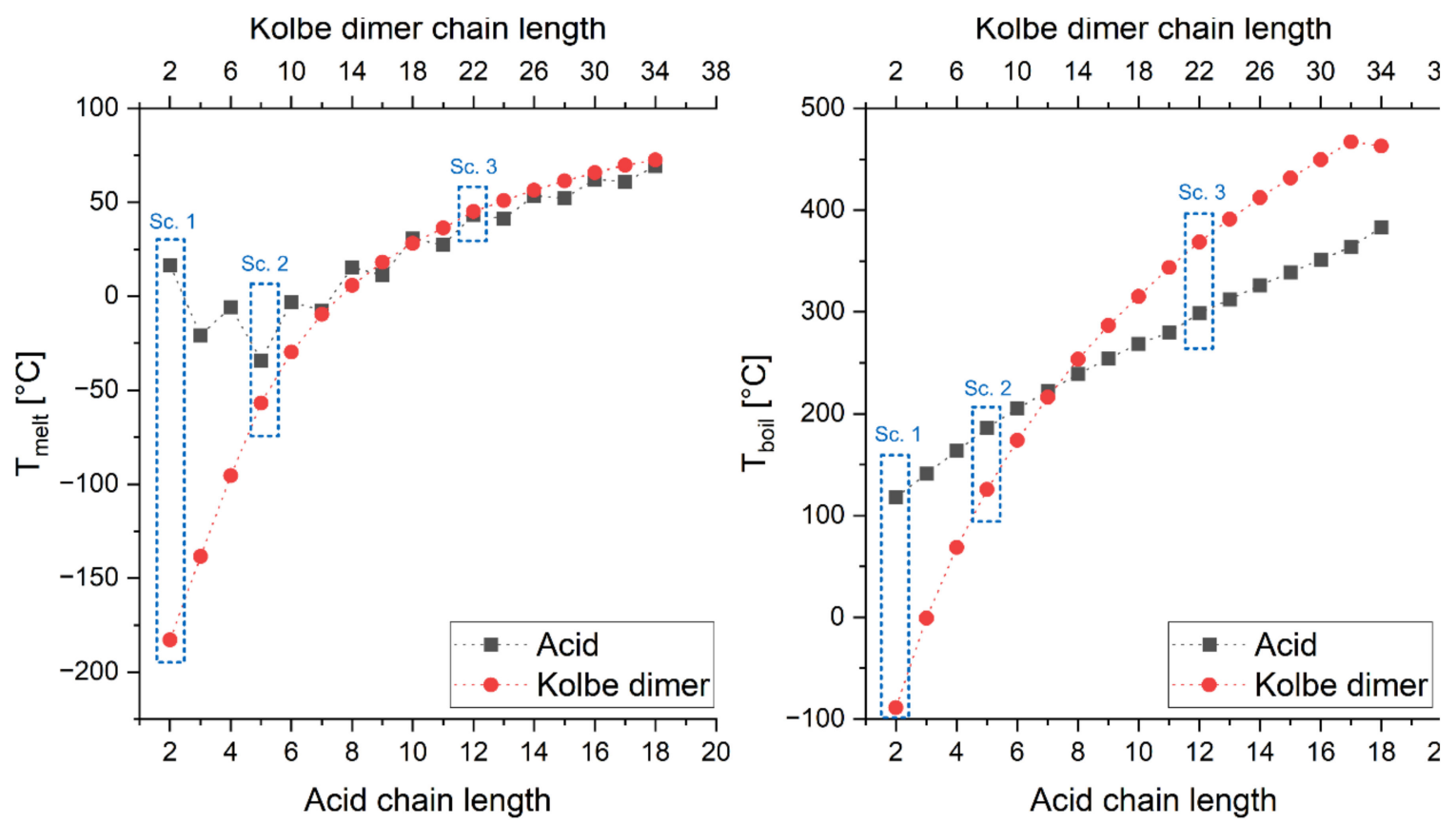

Figure 1. Melting and boiling point at ambient pressure of saturated fatty acids (FAs) and the Kolbe electrolysis products thereof; the lowers $\mathrm{x}$-axis refers to the FA carbon chain length $\mathrm{N}$ and the upper $\mathrm{x}$-axis refers to its corresponding Kolbe dimer chain length (2N-2); Blue dashed boxes indicate the compounds of the three scenarios (Sc.) discussed in Section 3.3 [24-26,29].

The corresponding products of the Kolbe electrolysis show a steady increase in melting point. The melting points of medium and long-chain FAs $(C \geq 7)$ and their Kolbe products differ by not more than $10^{\circ} \mathrm{C}$. Therefore, a separation of product and feedstock by solidliquid separation is unlikely.

The boiling points of the considered carboxylic acids increase nearly linear with chain length from $118{ }^{\circ} \mathrm{C}$ for acetic acid to $383{ }^{\circ} \mathrm{C}$ for stearic acid. The boiling point of the corresponding product is lower for alkanes smaller than tetradecane (C14) but higher for 
longer alkanes. The boiling points range from $-89^{\circ} \mathrm{C}$ for ethane to $467^{\circ} \mathrm{C}$ for dotriacontane $\left(\mathrm{C}_{34} \mathrm{H}_{70}\right)$. At room temperature, the raw FAs are liquid with chain length $\leq 9$ and solid with longer chains. The dimeric products ethane and butane are gases at ambient conditions. Except for these two compounds, the dimers appear in liquid state similar to the original FA.

The odd-even effect of the FA melting points is related to different intermolecular forces in the solid FA phase. The solid FA phase consists of a two-layer structure with alternating positioning of the carboxylic group. Even-numbered FAs allow a denser packing, higher crystallinity and stronger molecular bonding. Therefore, a higher level of thermal energy is required to overcome these cohesive forces, resulting in an increased melting point [30].

\subsection{Solubility of Fatty Acids and Their Products}

The phase state of the FA is influenced by the presence of water and basic compounds, such as sodium hydroxide. Table 1 gives the aqueous solubility and the logarithmic Octanol/Water Partition Coefficient $\lg \mathrm{K}_{\mathrm{OW}}$ of the different FAs, the corresponding sodium soaps (NaFA) and the Kolbe dimers $\left(\mathrm{R}_{2}\right)$. It is obvious that the water solubility of protonated FAs strongly decreases with chain length. While acetic and propionic acid are fully miscible in water at $25^{\circ} \mathrm{C}$, higher FAs are nearly insoluble. Sodium soaps are more water-soluble than FAs.

Table 1. Aqueous solubility and logarithmic Octanol/Water partition coefficient (lgK $\left.\mathrm{OW}_{\mathrm{W}}\right)$ of fatty acids, their sodium soaps (NaFA) and the corresponding Kolbe dimeric product $\left(\mathrm{R}_{2}\right)$; aqueous solubility at $25^{\circ} \mathrm{C}$ unless stated otherwise.

\begin{tabular}{|c|c|c|c|c|c|c|}
\hline \multirow[t]{2}{*}{$\begin{array}{c}\text { FA Chain } \\
\text { Length } \\
{[-]}\end{array}$} & \multicolumn{3}{|c|}{$\begin{array}{c}\text { Solubility } \\
\text { g/L }\end{array}$} & \multicolumn{3}{|c|}{$\begin{array}{c}\lg K_{O W} \\
{[-]}\end{array}$} \\
\hline & $\mathrm{FA}^{[a, b]}$ & $\mathrm{NaFA}^{[a, c, d]}$ & $R_{2}{ }^{[b]}$ & FA $^{[a]}$ & NaFA ${ }^{[a]}$ & $\mathbf{R}_{2}{ }^{[a]}$ \\
\hline 2 & soluble & soluble & 0.68 & -0.17 & & 1.8 \\
\hline 3 & soluble & soluble & 0.12 & 0.33 & & 2.9 \\
\hline 4 & 60 & & 0.02 & 0.79 & -3.2 & 3.9 \\
\hline 5 & 24 & soluble & 0.00 & 1.39 & & 5.2 \\
\hline 6 & 10.3 & & 0.00 & 1.92 & & 5.0 \\
\hline 7 & 2.82 & soluble & 0.00 & 2.42 & & 6.1 \\
\hline 8 & 0.72 & & 0.00 & 3.05 & -1.38 & 7.2 \\
\hline 9 & 0.21 & $70.4^{[\mathrm{e}]}$ & 0.00 & 3.42 & & 8.2 \\
\hline 10 & 0.06 & & 0.00 & 4.09 & & 8.4 \\
\hline 11 & 0.01 & $22.4^{[\mathrm{f}]}$ & 0.00 & 4.42 & & 10.2 \\
\hline 12 & 0.00 & 50 & 0.00 & 4.60 & & 11.2 \\
\hline 13 & 0.00 & 1.86 & 0.00 & & & 12.1 \\
\hline 14 & 0.00 & $<10$ & 0.00 & 6.11 & & 13.1 \\
\hline 15 & 0.00 & 0.58 & 0.00 & & & 14.1 \\
\hline 16 & 0.00 & insoluble & 0.00 & 7.17 & & 15.0 \\
\hline 17 & 0.00 & & 0.00 & & & 16.1 \\
\hline 18 & 0.00 & insoluble & & 8.23 & & \\
\hline
\end{tabular}

${ }_{\mathrm{a}}^{\mathrm{a}}[25],{ }^{\mathrm{b}}[27],{ }^{\mathrm{c}}[31],{ }^{\mathrm{d}}[32],{ }^{\mathrm{e}}$ near Krafft Point at $14^{\circ} \mathrm{C} ;{ }^{\mathrm{f}}$ near Krafft Point.

The logarithmic Octanol/Water Partition Coefficient $\lg \mathrm{K}_{\mathrm{OW}}$ indicates the distribution of the compound in equal amounts of Octanol and Water and thus gives information about its hydrophobic or hydrophilic property. $\mathrm{A} \lg \mathrm{K}_{\mathrm{OW}}$ of zero indicate equimolar distribution, while higher values reveal hydrophobicity. The Octanol/Water Partition Coefficient for sodium butyrate and sodium octanoate is reported as -3.2 and -1.38 , respectively, illustrating the hydrophilic character of those compounds due to the deprotonation of the carboxylic group [25]. Except for acetic acid, all the FAs exhibit a tendency towards solubilization in the hydrophobic phase. The dimeric Kolbe products are pure hydrocarbons and naturally solubilize in hydrophobic phases. Therefore, the FA could dissolve in the nonpolar phase generated by the production of the dimer during Kolbe electrolysis. 
Equimolar dosage of sodium hydroxide to the FA would inhibit the loss to the organic phase.

The deprotonation of the FA improves its aqueous solubility, as shown above. The dissociation equilibrium is described by the acid constant given as $\mathrm{pKa}$. The $\mathrm{pKa}$ value of FAs in the bulk phase, i.e., in sufficient distance to a phase interface, varies in the range of 4.7 to $5[25,29]$. These acid constants show that at a low molar concentration of 20-40 $\mu \mathrm{Mol} / \mathrm{L}$ in water, the deprotonated and protonated forms of FA appear in equimolar concentration. Furthermore, considerably higher pKa-values of up to 11 for long-chain FAs are reported at an aqueous-nonpolar interface instead of in the bulk phase [33,34]. This implies that FAs are not deprotonated at a phase boundary unless highly alkaline conditions are applied.

The desirable deprotonation of the FA happens at high pH-levels due to the addition of alkaline compounds. For $\mathrm{pH}$-adjustment and saponification, most basic monovalent compounds are applicable. Alkali metals, such as sodium and potassium are most suitable. Ammonia could work, if temperature and $\mathrm{pH}$ are not too high, as those parameters increase fugacity and loss of ammonia into the gaseous phase. Multivalent metals, such as the divalent calcium, form hardly soluble soap scum and are therefore the wrong choice in Kolbe electrolysis of FAs [35].

Alkaline conditions also improve solubility (see Table 1). However, long-chain FA salts remain poorly water-soluble [32]. Quast and Lucasson et al., reported the solubility of saturated FAs at $20^{\circ} \mathrm{C}$ depending on the $\mathrm{pH}$-value [36,37]. The solubility at a $\mathrm{pH}$ of 11 was up to two orders of magnitude higher than at $\mathrm{pH} 4$. However, the maximum solubility for the FAs of the chain lengths 10,12,14,16 and 18 did not exceed 54, 10, 0.86, 0.05 and 0.003 $\mathrm{g} / \mathrm{L}$, respectively.

In strongly alkaline conditions, long-chain FAs and alkali metals $\left(\mathrm{Me}^{+}\right)$form acid soaps according to the following Equation (15) [38]. It is however unknown, whether this interferes with Kolbe electrolysis.

$$
2 \mathrm{RCOO}^{-}+\mathrm{Me}^{+} \rightarrow \mathrm{Me}(\mathrm{RCOO})_{2}^{-}
$$

A further increase in the solubility is reached if the temperature is set above the Krafft temperature $\mathrm{T}_{\text {Krafft }}$ of the soap. The Krafft temperature, commonly used for specifying surfactants, refers to an interception of the curves of solubility and critical micelle concentration $(\mathrm{CMC})$, as sketched in Figure 2. It also marks the temperature above which the aqueous solubility increases rapidly [39].

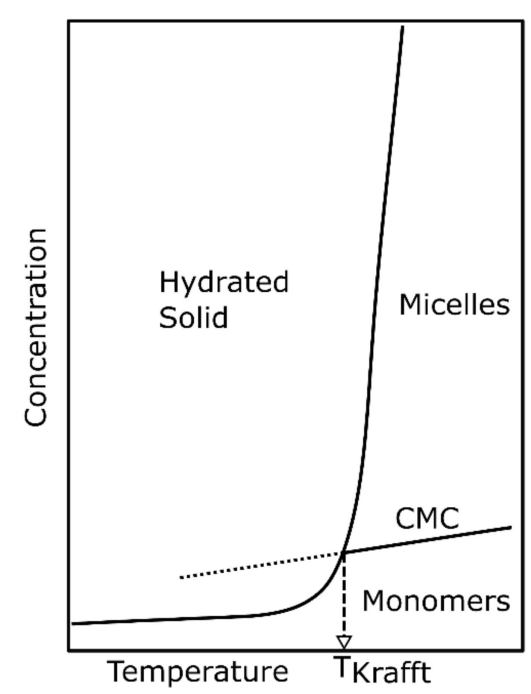

Figure 2. Generalized phase diagram of alkali soaps, own depiction inspired by Ogino et al. [31]. 
The Krafft temperature and the CMC of sodium soaps are given in Table 2. The Krafft temperatures differ less than $\pm 5^{\circ} \mathrm{C}$ from the melting points of the corresponding FAs. If more than one FA is present in a solution, the effective Krafft point lies between those of the different compounds [40].

It is known that bigger alkali cations decrease the Krafft temperature and enable solubilization of soap at lower temperatures [41]. Bulky cations, such as choline $\left(\mathrm{N}\left(\mathrm{CH}_{3}\right)_{3} \mathrm{OH}^{+}\right)$, are capable to further decrease the Krafft point of the respective soap. Substitution of sodium as counter ion by potassium or choline lowers the Krafft point by $15{ }^{\circ} \mathrm{C}$ and $30{ }^{\circ} \mathrm{C}$, respectively $[42,43]$. It should be further noted, that salts influence the Krafft temperature [44]. However, the direction of influence depends on the combination of salt and soap, i.e., different salts have either a salting-out or salting-in effect on the FAs.

The CMC values indicate that longer FAs have a stronger tendency to aggregate as micelles. Sodium soaps of propionic or butyric acid reveal no micelle building at $25{ }^{\circ} \mathrm{C}$ below molar concentrations of $3.5 \mathrm{~mol} / \mathrm{L}$ [45]. Potassium soaps exhibit comparable micellization as sodium soaps [46]. An example given, the CMC of sodium hexanoate and potassium hexanoate is reported as 145 and $126 \mathrm{~g} / \mathrm{L}$, respectively. The appearance of inorganic salts, such as sodium chloride, destabilize the micelles of the FAs and lower the solubility of FAs.

Table 2. Krafft temperature and critical micelle concentration (CMC) of different sodium soaps; CMC at $25^{\circ} \mathrm{C}$, unless stated otherwise.

\begin{tabular}{|c|c|c|}
\hline FA Chain Length & $T_{\text {Krafft }}[a, b]$ & $\mathrm{CMC}^{[\mathrm{c}, \mathrm{d}]}$ \\
\hline$[-]$ & ${ }^{\circ} \mathrm{C}$ & $\mathrm{g} / \mathrm{L}$ \\
\hline 4 & & $385.3[\mathrm{e}]$ \\
\hline 5 & & 291.7 [e] \\
\hline 6 & & $100.8^{[\mathrm{e}]}$ \\
\hline 7 & & $144.5^{[\mathrm{e}]}$ \\
\hline 8 & 17.1 & 58.2 \\
\hline 9 & 10.5 & 28.7 \\
\hline 10 & 31.1 & 18.3 \\
\hline 12 & 44.1 & 5.1 \\
\hline 13 & 39.8 & \\
\hline 14 & 53.2 & 1.7 \\
\hline 15 & 52.8 & \\
\hline 16 & 62.3 & 0.7 \\
\hline 18 & 71 & 0.1 \\
\hline
\end{tabular}

${ }^{\mathrm{a}}[25],{ }^{\mathrm{b}}[33],{ }^{\mathrm{c}}[36],{ }^{\mathrm{d}}[46] ;{ }^{\mathrm{e}}$ at $20^{\circ} \mathrm{C}$.

\subsection{Basic Process Design}

This section presents the basic process design for three different feedstocks: acetic acid $\left(\mathrm{CH}_{3} \mathrm{COOH}\right)$, valeric acid $\left(\mathrm{C}_{4} \mathrm{H}_{9} \mathrm{COOH}\right)$, and lauric acid $\left(\mathrm{C}_{11} \mathrm{H}_{23} \mathrm{COOH}\right)$. Every process scenario consists of a Kolbe reactor, a downstream product purification, and a recycling loop for unconverted feedstock and catalyst. Where applicable, heating or cooling units are added to the system.

The corresponding reactions take place in the Kolbe reactor that is treated as a blackbox model. The reaction equations are shown in Table 2. The assessed downstream processing differs among the scenarios as the respective products show different thermophysical characteristics. However, since the gases hydrogen and carbon dioxide always occur, a gas-liquid separation is part of each scenario. After an optional second separation step, the unconverted feedstock and the alkaline catalyst are recycled back to the Kolbe reactor. The Kolbe products might be further refined in separation steps to meet the required purity. Additionally, every process needs a thermal energy management with heat exchanger equipment to convey away the heat generated in the electrolysis unit. 


\subsubsection{Acetic Acid as Feedstock}

The utilization of acetic acid as feedstock in a Kolbe process is depicted in Figure 3. This compound is fully miscible in water and, thus, the Kolbe electrolysis (KE) can work at ambient temperature. The initial acid concentration should be at least $1 \mathrm{~mol} / \mathrm{L}$, as higher concentrations allow for a higher Coulomb efficiency and a lower cell voltage [47]. An alkaline catalyst, such as sodium hydroxide, in equimolar concentration to the feedstock is added to the feed.

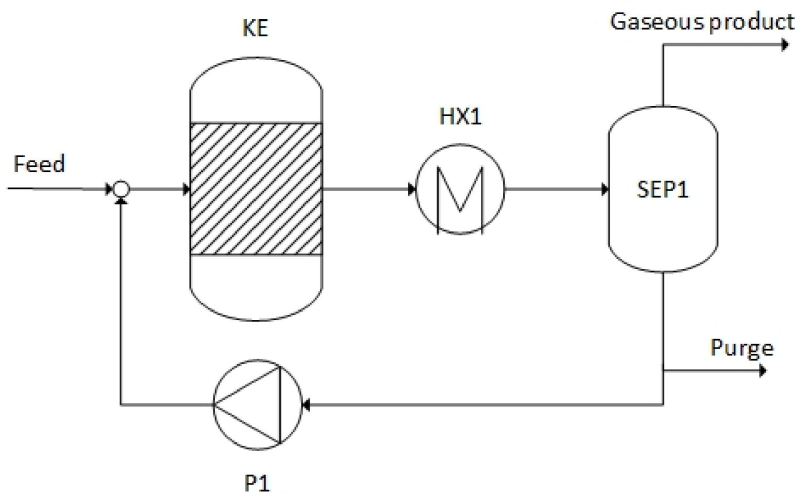

Figure 3. Process flow diagram for the production of ethane via Kolbe electrolysis (KE: Kolbe electrolysis, HX1: heat exchanger, SEP1: liquid-gas separation, P1: pump).

The excess heat during the reaction is then removed in a heat exchanger (HX1). The products of the Kolbe electrolysis are all gaseous. Consequently, the first separation step (SEP1) separates the gas from the liquid phase, which results in a simple process design. If methane was produced according to Equation (8), it leaves the plant with the gaseous product. The liquid is pumped back and mixed with fresh acetic acid (P1). Depending on the concentration of acetic acid in the feed, a certain amount of the liquid has to be discharged as purge stream to avoid an accumulation of water in the system. Since all products are gaseous, the problem of gas bubbles in the liquid and on surfaces arises. This phenomenon causes the effective electrode area in the electrolysis cell to decrease leading to a lower reaction rate in the reactor compared to a gas-free electrode area.

Through the simple process design, a flexibilization of the process is easily doable. Flexibly operating the electrolysis unit leads to a fluctuating mass flow in the process, which can be regulated by the pump. Furthermore, the functioning of the separation process is independent of the mass flows.

The carbon efficiency in this scenario is limited to $50 \%$, as the stoichiometry of the reaction requires two moles of carbon dioxide per mole of ethane produced. The energetic efficiency is limited to $27.9 \%$. The minimum charge required is 6,417,359 C per kg of Kolbe product. With regard to a reported maximum current efficiency of $85 \%$ [47], the specific charge per product would amount to $8,021,699 \mathrm{C} / \mathrm{kg}$.

Further gas separation processes can be added to refine the gases (not depicted). Separation of carbon dioxide would allow an injection of ethane, methane and hydrogen into the gas grid. Usually, the injection of hydrogen leads to a lower Wobbe index in the gas grid $\left(\mathrm{W}_{\mathrm{s}, \mathrm{H} 2}=37.2 \mathrm{MJ} / \mathrm{m}^{3}\right)$ [48]. The co-injection of ethane could compensate for the reduction in Wobbe index $\left(\mathrm{W}_{\mathrm{s}, \mathrm{C} 2 \mathrm{H} 6}=57.5 \mathrm{MJ} / \mathrm{m}^{3}\right)$ [48]. The same is true for the volumetric heating value, which is lowered through the injection of hydrogen $\left(\mathrm{LHV}_{\mathrm{H} 2}=9.8 \mathrm{MJ} / \mathrm{m}^{3}\right)$ [48]. The lower heating value of ethane could compensate for the reduction $\left(\mathrm{LHV}_{\mathrm{C} 2 \mathrm{H} 6}=58.9 \mathrm{MJ} / \mathrm{m}^{3}\right)$ [48] Reported values are valid at $25^{\circ} \mathrm{C}$ and 1.013 bar.

\subsubsection{Valeric Acid as Feedstock}

The scenario shown in Figure 4 represents the conversion of the mid-chain FA valeric acid to n-octane as the main product. The feedstock is a fully soluble aqueous mixture 
of valeric acid and the catalyst sodium hydroxide at ambient temperature. The potential side-product 1-butanol tends to build esters with valeric acid, generating butyl valerate.

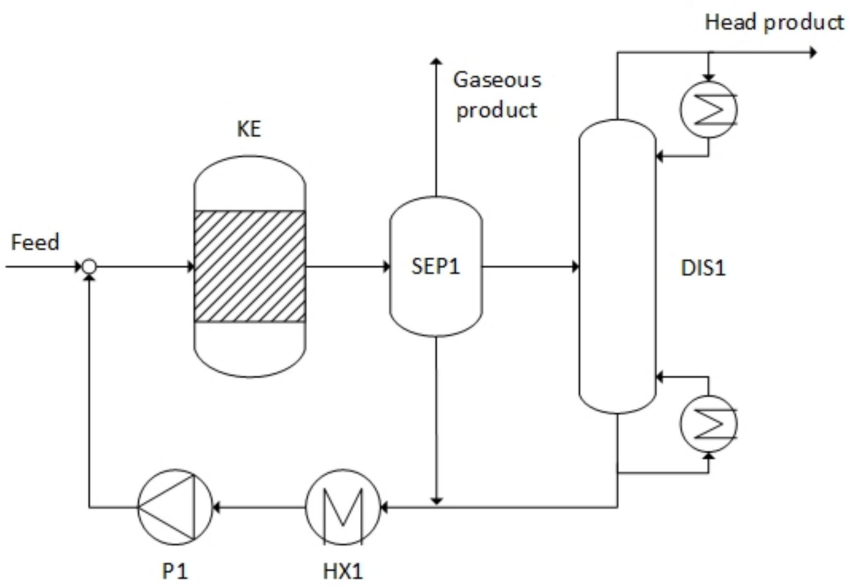

Figure 4. Process flow diagram for the production of n-octane via Kolbe electrolysis (KE: Kolbe electrolysis, SEP1: liquid-liquid-gas separation, DIS1: distillation, HX1: heat exchanger, P1: pump).

The separator following the Kolbe electrolysis is a three-phase separator, which splits the mixture into a gaseous phase, an aqueous phase and a nonpolar phase. The aqueous phase of the first separation step contains water, 1-butanol and dissociated valeric acid. Sodium valerate accumulates preferably in the aqueous phase as the values for $\lg \mathrm{K}_{\mathrm{OW}}$ for NaFAs in Table 1 indicate. The gaseous phase is mainly composed of hydrogen and carbon dioxide. The nonpolar phase enters a distillation column DIS1, which is used to purify octane as head product and to recover feedstock and the ester for recycling. The aqueous phase and the distillation bottom product are both recycled. In this scenario, the heat removal HX1 is integrated in the recycling loop, as higher temperatures are favorable for the distillation input.

The nonpolar phase contains n-octane and poorly water-soluble butyl valerate [25]. Traces of polar components are also present in the nonpolar phase. Nevertheless, dissolved valeric acid and butanol will be present in the stream sent to distillation in very small amounts. Table 3 shows the boiling points of the present liquid compounds in the system. The distillation process should not present difficulties. The boiling points of n-octane and butyl valerate are far apart from each other and an additional check in Aspen Plus showed no azeotrope for the compounds (see Appendix C). Eventually occurring non-idealities introduced through the presence of certain compounds in the distillation column need to be further investigated.

Table 3. Boiling points (at 1 bar) of the present compounds in the process [25].

\begin{tabular}{cc}
\hline Compound & Boiling Point \\
\hline Water & $100^{\circ} \mathrm{C}$ \\
1-butanol & $117^{\circ} \mathrm{C}$ \\
N-octane & $126^{\circ} \mathrm{C}$ \\
Butyl valerate & $186^{\circ} \mathrm{C}$ \\
Valeric acid & $186^{\circ} \mathrm{C}$ \\
\hline
\end{tabular}

Depending on the conversion rate and the initial feedstock concentration, the critical micelle concentration of valeric acid ( $1.22 \mathrm{~mol} / \mathrm{L}$, see Table 2$)$ might be exceeded. Therefore, micelles could stabilize nonpolar droplets in the aqueous, which could cause problems in the SEP1 unit. Destroying the micelles, for example by ultrasonic waves, might be necessary. According to Aspen simulations, the ester equilibrium constant $K$ of the esterification equals $2.7 \times 10^{6}$ (for $\mathrm{T}=20^{\circ} \mathrm{C}$ and $p=1 \mathrm{bar}$ ). Consequently, the equilibrium is shifted towards 
the ester and water and can tremendously affect the composition of the mixtures at every point of the process.

The longer carbon chain of valeric acid in comparison to acetic acid allows a theoretical carbon efficiency of $80 \%$. The mass-specific minimum charge is $1,691,681 \mathrm{C} / \mathrm{kg}$. Stang and Harnisch reported a Coulomb efficiency for the conversion of valeric acid and their Coulomb efficiency reached up to $90 \%$ [20]. The maximum energetic efficiency is $54.6 \%$. The product n-octane is widely applicable in chemical industry or potentially high-grade fuel.

\subsubsection{Lauric Acid as Feedstock}

Processing lauric acid to docosane requires a simple process design (Figure 5). The lower temperature limit of the Kolbe electrolysis is set by the melting point of docosane at $45.1^{\circ} \mathrm{C}$. Excess usage of potassium hydroxide is proposed to lower the Krafft temperature of the lauric acid soap and increase the solubility further. A pH value higher than 9.3 would avoid micellization of potassium laurate [49].

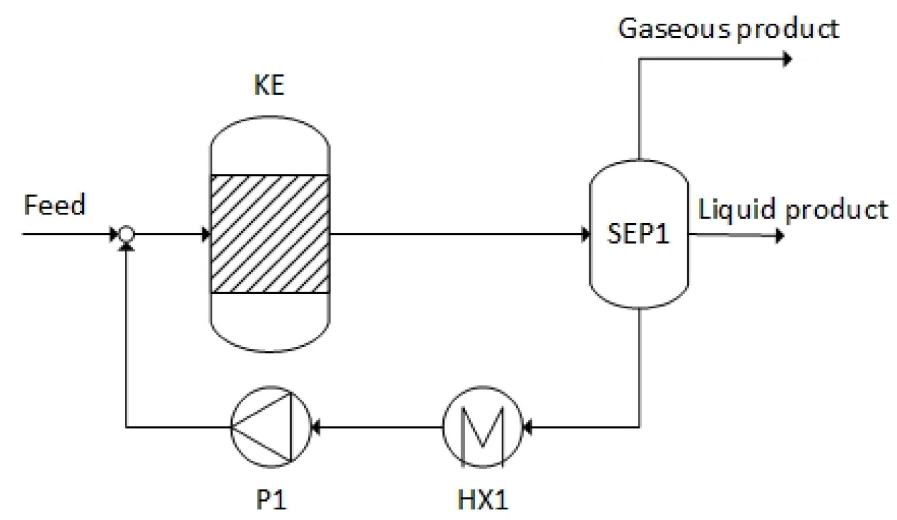

Figure 5. Process flow diagram for the production of docosane via Kolbe electrolysis (KE: Kolbe electrolysis, HX1: heat exchanger, SEP1: liquid-liquid-gas separation, P1: pump).

The feedstock enters the Kolbe electrolysis and afterwards the three-phase separator. Similarly to the scenario converting valeric acid, the gaseous product mainly consists of carbon dioxide and hydrogen. The deprotonated lauric acid remains in the aqueous phase. The alcoholic side-product 1-undecanol and the corresponding ester undecyl laurate are highly hydrophobic and, therefore, accumulate in the nonpolar phase. The risk of a stable liquid-liquid emulsion is relatively low, as the high $\mathrm{pH}$-value decreases surface activity of the lauric acid, as Saleeb et al. demonstrated [50]. The heat exchanger HX1 is integrated with the recycling loop because high temperatures in SEP1 avoid precipitation of solids in the three-phase-decanter and enables a better gas separation through a lower gas solubility at higher temperatures.

The theoretical carbon efficiency is $92 \%$ and the maximum energetic efficiency $\eta_{e n, \text { min }}$ is $75.9 \%$. The reaction requires a charge of $622,343 \mathrm{C}$ per $\mathrm{kg}$ of product assuming ideal conditions. The product can be used as a part of lubricants or in cosmetics. Depending on the application, further purification might be necessary. A distillation of the liquid product is not applicable as docosane decomposes before its boiling point of $369^{\circ} \mathrm{C}$ is reached.

\subsection{Comparision of the Scenarios}

Table 4 summarizes the main properties of the Kolbe scenarios under investigation. The conversion of short-chain FAs generates gaseous hydrocarbons, while mid and longchain FAs produce liquid products. The downstream processing has to be chosen according to the thermophysical properties of the present compounds. In general, the product is always easily removable from the aqueous phase, either as gas or as organic phase. 
Table 4. Properties of the Kolbe processes based on three different linear saturated FA.

\begin{tabular}{|c|c|c|c|}
\hline Feedstock & Acetic Acid & Valeric Acid & Lauric Acid \\
\hline Product & Ethane & n-octane & \multirow{3}{*}{$\begin{array}{l}\text { Docosane } \\
\text { Hydrogen, carbon dioxide, } \\
\text { 1-undecanol, undecyl laurate } \\
\text { Excess molar to feedstock, } \\
\text { preferably KOH }\end{array}$} \\
\hline Side products & $\begin{array}{l}\text { Hydrogen, carbon dioxide, } \\
\text { methane }\end{array}$ & $\begin{array}{l}\text { Hydrogen, carbon dioxide, } \\
\text { 1-butanol, butyl valerate }\end{array}$ & \\
\hline Catalyst amount & Equimolar to feedstock & Equimolar to feedstock & \\
\hline Downstream processing & Liquid-gas separation & $\begin{array}{l}\text { Liquid-liquid-gas separation } \\
\text { and distillation }\end{array}$ & Liquid-liquid-gas separation \\
\hline Product utilization & $\begin{array}{l}\text { Natural gas substitute, } \\
\text { specialty gas }\end{array}$ & Specialty chemicals, fuel & Lubricant, cosmetics \\
\hline Max. carbon efficiency ${ }^{[a]}$ & $50 \%$ & $80 \%$ & $92 \%$ \\
\hline $\begin{array}{l}\text { Required charge per product } \\
{[\mathrm{a}, \mathrm{b}]}\end{array}$ & $6,417,359 \mathrm{C} / \mathrm{kg}$ & $1,691,681 \mathrm{C} / \mathrm{kg}$ & $622,343 \mathrm{C} / \mathrm{kg}$ \\
\hline Maximum energetic efficiency & $27.9 \%$ & $54.6 \%$ & $75.9 \%$ \\
\hline Operating temperature & $\approx 20^{\circ} \mathrm{C}$ & $\approx 20^{\circ} \mathrm{C}$ & $>45.1{ }^{\circ} \mathrm{C}^{[\mathrm{c}]}$ \\
\hline
\end{tabular}

a assuming no formation of side products; ${ }^{\mathrm{b}}$ assuming a Coulomb efficiency of $100 \%{ }^{\mathrm{c}}$ above Krafft point.

The possible utilization pathways of the products differ broadly due to their respective properties. The addition of an alkaline catalyst is crucial for all systems, but most important with long-chain FAs due to its impact on aqueous FA solubility. Concerning the best carbon yield and lowest product-specific charge requirement, long-chain FAs are favorable as feedstock. The melting points of the products indicate the minimum Kolbe temperature applicable.

\subsection{General Aspects of Process Design}

The following sections summarize aspects that have to be considered for process development.

The acid-base equilibrium can influence the process design. Alcohols and esters are side-products of the Kolbe electrolysis (Equations (5) and (6)). The equilibrium influences the availability of compounds in the streams for reaction in the Kolbe electrolysis. Especially, distillation processes are subject to the equilibrium since the concentrations change significantly on the different stages.

The evolution of gaseous products could lead to process difficulties in the electrochemical reactor and the separation step. Extensive foam production and coverage of electrode surfaces could increase the electric resistance in the system. Foam could also appear during the product separation step.

Flexibilizing the electricity demand as a response to a volatile regenerative energy generation is one major advantage of the process. The Kolbe electrolyser and the first separation step for small and medium-chain FAs work at ambient temperatures and, thus, need no heat-up phase after restarting. For long-chain FA electrolysis, the reactor probably needs proper insulation and slightly longer start-up time, until the designated temperature is reached. The flexible operation of a distillation column (scenario based on valeric acid) is more challenging. However, increasing the volume for product storage after the first separation step would allow a continuous feed to the distillation column. The flexibilization of the processes does not pose extreme difficulties and should be easily implementable.

Through the reaction in the electrolysis cell, the concentration of the carboxylic acid after the cell will decrease. To maintain a high concentration in the electrolysis process, a high feed concentration of the carboxylic acid to the process has to be applied. A purge stream might be required to avoid the accumulation of side products and impurities or for removal of surplus water. A purge stream is not necessary if the side products are removed as traces with the main product stream. The excess heat, generated by the electrolysis, has to be preferably removed from the recycling stream. In some cases, the generated heat is beneficial for further separation steps such as distillation or the separation in the scenario with lauric acid to avoid the solidification of the product stream. 
The possible separation pathways for the products of the Kolbe electrolysis differ broadly but rely on standard equipment. The three scenarios illustrate that the Kolbe product can either be removed as gaseous phase or as organic phase in an ordinary settler. A second downstream step, such as distillation, might be necessary for further purification. All of the processes are applicable in well-established apparatus and thus should be easily and cost-efficiently deployed. It can be assumed that the investment cost of such a plant is low since all required process equipment is based on standard components in the three presented cases. Furthermore, pressure and temperature are moderate. Low investment cost would be beneficial for a flexible operation of the plant since less full load hours increase the impact of investment cost on the overall production cost.

\section{Discussion}

The addition of alkaline catalyst in the three scenarios was chosen to assure deprotonation and to gain high solubility of the FA. However, as alkaline conditions catalyze the further oxidation of the radical dimer to the corresponding carbenium ion, this could support the production of the alcohol and olefin side products [8,9]. As the $\mathrm{pH}$ value near the electrode can be significantly lower than in the bulk, it remains unclear whether this non-Kolbe product selectivity actually happens or not $[8,20]$. The solubility of short and medium-chain FAs is less critical but, in the case of long-chain FAs, this can cause problems due to contradicting requirements. This conflict can be solved by adding a supporting electrolyte to the solution which is capable to lower the Krafft temperature of the FA. Bulky salts of organic cations such as tetrabutylammonium bromide are suitable for this purpose [44].

The three presented process designs are specific to the feedstocks used. Nevertheless, every Kolbe process will generally be similar containing an electrolysis unit, a recycle stream, a pump, heat transfer equipment and a separation of products and side products from the stream sent to recycling. With a similar process design based on standard equipment, the low investment costs and load flexibility of the process can be transferred to other processes based on a different feedstock. The process design has to be validated with a process simulation and experimental data to confirm the chosen processes. For example, it can be argued that an additional gas dryer is necessary for the scenario acetic acid before the gas can be injected into the gas grid. Another example is the purification through distillation in the scenario using valeric acid as feedstock. Here, the acid-base equilibrium can influence the purity of the head product.

Two effects that have not been discussed is foaming and fouling. Since the operational experience of continuously working cells is limited, the effects on the process cannot be assessed. The amphiphilic character of FAs makes them surface-active compounds and leads to enrichment at polar-disperse phase boundaries. They accumulate at the interface of aqueous and gaseous phase and most probably at water-organic liquid phases as well. It can be assumed that the surface, consisting of generated gas bubbles of $\mathrm{CO}_{2}, \mathrm{H}_{2}$ or gaseous hydrocarbons, will be stabilized by the FAs. Foam formation can be problematic for gas removal. Further studies are mandatory to clarify the importance of this issue. Fouling has not been analyzed yet. It can be assumed that fouling on the electrodes lowers the efficiency of the process. Research has to be conducted on whether fouling poses a problem in Kolbe electrolysis.

Reliable data on the conversion of carboxylic acids via Kolbe electrolysis are not available yet. Several studies show the feasibility of Kolbe electrolysis, but the complex interaction of the numerous parameters is not presented consistently. Due to the vague data availability, this paper could not present a simulation of the processes. To address this research gap, experimental data focusing on the information required for process development are needed. Investigations on parameters such as side product generation, coulomb efficiencies, heat generation, kinetics and recycling rates in the electrochemical cell are important for further development. In particular, the side product generation and the effects of side products (from the recycling stream) in the electrolysis cell have to be 
investigated. Furthermore, the optimal operating conditions and setup of the cell have to be determined. As an example, the coulomb efficiencies for the conversion of valeric acid to n-octane range from $40 \%$ to $90 \%$ (reaction conditions differ) $[14,20,22,51]$. The selectivity ranges from $40 \%$ to $96 \%[14,20,22,51]$. Nilges et al. reported a product distribution for a $1 \mathrm{M}$ valeric acid feed between n-octane, n-butyl valerate and butanol of $72 \%, 18 \%$ and $2 \%$, respectively [14]. A lower feed concentration leads to a higher fraction of byproducts [14]. Another study reports at room temperature a product composition of $40 \%$ n-octane and $55-60 \%$ esters [20]. At $4{ }^{\circ} \mathrm{C}$, the fraction of n-octane increases to $57 \%$ and the fraction os esters is $40 \%$ [20]. In both cases, minor fractions of ketones, alcohols and dibutyl peroxide could be found [20]. The fraction of the byproduct alcohol is of minor importance. The formed ester is of higher importance for process design.

The reaction enthalpies of the Kolbe reaction, as well as the side reactions towards alcohols and esters, reveal a slightly positive value indicating endothermic conditions ranging from $21-125 \mathrm{~kJ} / \mathrm{mol}$ (see Table 2). However, the minimum electrical input exceeds the reaction enthalpy by two orders of magnitude. The surplus of electric work increases the temperature in the Kolbe reactor. Therefore, it is necessary to remove heat from the reactor, either by a cooling system or with the fluid stream leaving the reactor. The energetic efficiency is rather low as the determined theoretical maximum reaches not more than $76 \%$. Acetic acid has a relatively low higher heating value but consumes the same amount of electricity on a molar basis as long-chain FAs. Therefore, the energetic efficiency of acetic acid conversion is lower than of longer FA conversions.

The high electric demand is mainly driven by the relatively high voltage applied to gain sufficient conversion rates. The assumed voltage of $2.5 \mathrm{~V}$ was presented as a minimum and other authors report much higher voltage of up to $29 \mathrm{~V}$ [10]. For reducing the electric power demand, the decrease in the voltage applied is crucial. Further development of catalyzing electrodes could possibly improve process efficiency.

\section{Conclusions}

The results shown above present a first step towards a process development of a continuously working electrochemical conversion of carboxylic acids to hydrocarbons. Based on thermophysical parameters and process design for three scenarios, the study investigated the challenges and opportunities of a continuously working Kolbe process.

The different products of a Kolbe electrolysis differ in properties and applicability. The optional products range from gaseous or liquid fuels to specialty chemicals. The theoretical ideal carbon efficiency and mass-specific charge requirement improve with longer FA chain length. The alkaline catalyst takes on an important role during the solubilization of the FA in an aqueous medium. In addition, most Kolbe products will be found in an organic phase allowing for easy separation from the aqueous phase.

The three scenarios illustrate the different characteristics during the process, especially in downstream processing. Every process involves a gas separation step. Further separations such as organic phase separation or distillation might be necessary for some processes. In general, the Kolbe process relies on simple standard process equipment with low investment costs. Additionally, the process can be easily flexibilized since most process steps can deal with fluctuating mass flows in the process.

It was not possible to include kinetic data, selectivity parameters or yields into the scenario, as the data in literature are based on different conceptual designs and batch experiments. Furthermore, no data were available regarding specific requirements for downstream processing. Process simulations fed with experimental data allow for further investigations of the production process. From the simulation, calculated material and energy balances can subsequently be used to assess the processes in terms of economics and sustainability. 
Author Contributions: D.K. and W.W. share the first authorship; Conceptualization, D.K. and W.W.; Data curation, D.K. and W.W.; Formal analysis, D.K. and W.W.; Investigation, D.K. and W.W.; Methodology, D.K. and W.W.; Resources, D.K. and W.W.; Software, D.K. and W.W.; Supervision, M.G.; Visualization, D.K. and W.W.; Writing-original draft, D.K. and W.W.; Writing-review and editing, D.K. and W.W. All authors have read and agreed to the published version of the manuscript.

Funding: This research received no external funding.

Conflicts of Interest: The authors declare no conflict of interest.

\section{Appendix A}

Table A1. Standard enthalpies of formation $\Delta h_{F, i}^{0}$ at $25^{\circ} \mathrm{C}$ and 1.013 bar at given phase state $(\mathrm{g}, \mathrm{l})$; values were retrieved from Aspen Plus database.

\begin{tabular}{cccccc}
\hline Compound & $\boldsymbol{\Delta} \boldsymbol{h}_{\boldsymbol{F}, \boldsymbol{i}}^{0}$ & Compound & $\boldsymbol{\Delta} \boldsymbol{h}_{\boldsymbol{F}, \boldsymbol{i}}^{0}$ & Compound & $\boldsymbol{\Delta} \boldsymbol{h}_{\boldsymbol{F}, \boldsymbol{i}}^{0}$ \\
\hline & $\mathrm{kJ} / \mathrm{mol}$ & & $\mathrm{kJ} / \mathrm{mol}$ & & $\mathrm{kJ} / \mathrm{mol}$ \\
\hline $\mathrm{H}_{2} \mathrm{O}(\mathrm{l})$ & -285.8 & & & & \\
$\mathrm{CO}_{2}(\mathrm{~g})$ & -393.5 & & & \\
$\mathrm{H}_{2}(\mathrm{~g})$ & 0.0 & & & & \\
$\mathrm{CH}_{3} \mathrm{COOH}(\mathrm{l})$ & -457.1 & $\mathrm{C}_{4} \mathrm{H}_{9} \mathrm{COOH}(\mathrm{l})$ & -541.3 & $\mathrm{C}_{11} \mathrm{H}_{23} \mathrm{COOH}(\mathrm{l})$ & -738.6 \\
$\mathrm{C}_{2} \mathrm{H}_{6}(\mathrm{~g})$ & -83.8 & $\mathrm{C}_{8} \mathrm{H}_{18}(\mathrm{l})$ & -250.2 & $\mathrm{C}_{22} \mathrm{H}_{46}(\mathrm{l})$ & -603.6 \\
$\mathrm{CH}_{4}(\mathrm{~g})$ & -74.5 & $\mathrm{C}_{4} \mathrm{H}_{9} \mathrm{OH}(\mathrm{l})$ & -328.6 & $\mathrm{C}_{11} \mathrm{H}_{23} \mathrm{OH}(\mathrm{l})$ & -506.5 \\
& & $\mathrm{C}_{9} \mathrm{H}_{18} \mathrm{O}_{2}(\mathrm{l})$ & -614.0 & $\mathrm{C}_{23} \mathrm{H}_{46} \mathrm{O}_{2}(\mathrm{l})$ & $-886.8^{[\mathrm{a}]}$ \\
\hline
\end{tabular}

[a] The Aspen Plus database does not contain this compound (undecanoic laurate); thus, its enthalpy of formation was estimated based on its chemical structure within Aspen Plus.

Table 2. Reactions considered for process development in the Kolbe electrolysis cell with respective enthalpy of reaction $\Delta h_{R}^{0}$ per mol of converted fatty acid at $25^{\circ} \mathrm{C}$ and 1.013 bar; phase states of the compounds involved are considered as given in Table A1.

\begin{tabular}{ccc}
\hline Producttitle & Reaction Equation & $\Delta \boldsymbol{h}_{\boldsymbol{R}}^{0}$ \\
\hline Processing of acetic acid & & $\mathrm{kJ} / \mathrm{mol}$ \\
\hline Kolbe product: ethane & $2 \mathrm{CH}_{3} \mathrm{COOH} \rightarrow \mathrm{C}_{2} \mathrm{H}_{6}+\mathrm{H}_{2}+2 \mathrm{CO}_{2}$ & -21.7 \\
Side product: methane & $2 \mathrm{CH}_{3} \mathrm{COOH} \rightarrow 2 \mathrm{CH}_{4}+2 \mathrm{CO}_{2}$ & 10.9 \\
\hline Processing of valeric acid & & 22.6 \\
\hline Kolbe product: n-octane & $2 \mathrm{C}_{4} \mathrm{H}_{9} \mathrm{COOH} \rightarrow \mathrm{C}_{8} \mathrm{H}_{18}+\mathrm{H}_{2}+2 \mathrm{CO}_{2}$ & 104.9 \\
Side product: 1-butanol & $2 \mathrm{C}_{4} \mathrm{H}_{9} \mathrm{COOH}+2 \mathrm{H}_{2} \mathrm{O} \rightarrow 2 \mathrm{C}_{4} \mathrm{H}_{10} \mathrm{O}+2 \mathrm{H}_{2}+2 \mathrm{CO}_{2}$ & 37.5 \\
Side product: butyl valerate & $2 \mathrm{C}_{4} \mathrm{H}_{9} \mathrm{COOH} \rightarrow \mathrm{C}_{9} \mathrm{H}_{18} \mathrm{O}_{2}+\mathrm{H}_{2}+\mathrm{CO}_{2}$ & \\
\hline Processing of lauric acid & & \\
\hline Kolbe product: docosane & $2 \mathrm{C}_{11} \mathrm{H}_{23} \mathrm{COOH} \rightarrow \mathrm{C}_{22} \mathrm{H}_{46}+\mathrm{H}_{2}+2 \mathrm{CO}_{2}$ & 43.3 \\
Side product: 1-undecanol & $2 \mathrm{C}_{11} \mathrm{H}_{23} \mathrm{COOH}+2 \mathrm{H}_{2} \mathrm{O} \rightarrow 2 \mathrm{C}_{11} \mathrm{H}_{24} \mathrm{O}+2 \mathrm{H}_{2}+2 \mathrm{CO}_{2}$ & 43.3 \\
Side product: undecyl laurate & $2 \mathrm{C}_{11} \mathrm{H}_{23} \mathrm{COOH} \rightarrow \mathrm{C}_{23} \mathrm{H}_{46} \mathrm{O}_{2}+\mathrm{H}_{2}+\mathrm{CO}_{2}$ & 98.5
\end{tabular}

\section{Appendix B}

Appendix B describes the calculation of the maximum energetic efficiency $\eta_{e n, \max }$ in detail. The calculation of a theoretical energetic efficiency is the energy balance on the Kolbe reactor. For an energy balance on the Kolbe electrolysis reactor, the relevant inputs are the electric work $w_{e l, \text { min }}$ and the enthalpy of the FA $h_{i n}$. The output is the enthalpy of the product $h_{\text {out }}$ (all on a molar basis, Equation (A1)). All calculations described here rely on the assumption that all input and output compounds appear at $25{ }^{\circ} \mathrm{C}$ and $1.013 \mathrm{bar}$. Furthermore, a Coloumb efficiency of $100 \%$ was assumed.

$$
\eta_{e n, \max }=\frac{h_{\text {out }}}{h_{\text {in }}+w_{\text {el, min }}}
$$


The higher heating value $h h v_{F A}$ of the feedstock in $\mathrm{kJ} / \mathrm{mol}$ can be used to describe the enthalpy input $h_{i n}$. Differences in temperature of the input and output streams are negligible due to the mild temperatures during Kolbe electrolysis. If the pure-substance molar enthalpies are known, the $h h v_{F A}$ of the hydrocarbon $\mathrm{C}_{\mathrm{a}} \mathrm{H}_{\mathrm{b}} \mathrm{O}_{\mathrm{c}}$ can be calculated by Equation (A2). The enthalpy output $h_{\text {out }}$ can be expressed as the sum of $h h v_{F A}$ and its the reaction enthalpy during Kolbe electrolysis $\Delta h_{R}^{0}($ Kolbe $)$.

$$
\begin{gathered}
h h v_{F A}=-\Delta h_{R}^{0}(\text { combustion })=-\left(-h_{F, F A}^{0}-\left(a+\frac{b}{4}-\frac{c}{2}\right) \times h_{F, \mathrm{O}_{2}}^{0}+a \times h_{F, \mathrm{CO} 2}^{0}+\frac{b}{2} \times h_{F, H_{2} \mathrm{O}}^{0}\right) \\
w_{\text {el,min }}=q_{\text {min,molar }} \times E_{\text {min }}=z \times F \times E_{\text {min }}
\end{gathered}
$$

The minimum electric energy input $w_{e l, \text { min }}$ is the product of the transferred electric charge and voltage (Equation (A3)). The minimum specific electric charge $q_{\text {min,molar }}$ is determined by the minimum electron transfer during Kolbe electrolysis. $z$ of the feedstock is 1 and, therefore, $q_{\text {min,molar }}$ equals the Faraday constant $F$. The minimum electric voltage $E_{\text {min }}$ depends on the operating conditions. One theoretical value given in literature is $2.5 \mathrm{~V}$ [20]. These assumptions allow the calculation of the energetic efficiency $\eta_{e n, \max }$ as given by Equation (A4). The values for $h h v_{F A}, \Delta h_{R}^{0}\left(\right.$ Kolbe), $w_{e l, \text { min }}$ and $\eta_{e n, \text { max }}$ for the three investigated scenarios are given in Table A3.

$$
\eta_{e n, \max }=\frac{h h v_{F A}+\Delta h_{R}^{0}(\text { Kolbe })}{h h v_{F A}+E_{\min } \times F}
$$

Table A3. Molar higher heating value of the FAs $h h v_{F A}$, the reaction enthalpy of the Kolbe process $\Delta h_{R}^{0}($ Kolbe $)$, the minimum electric work and the maximum theoretical energetic efficiency of the three scenarios.

\begin{tabular}{ccccc}
\hline & Unit & $\begin{array}{c}\text { Scenario } \\
\text { Acetic Acid }\end{array}$ & $\begin{array}{c}\text { Scenario } \\
\text { Valeric Acid }\end{array}$ & $\begin{array}{c}\text { Scenario } \\
\text { Lauric Acid }\end{array}$ \\
\hline$h h v_{F A}$ & $\mathrm{~kJ} / \mathrm{mol}$ & 901.5 & 2855.3 & 7413.1 \\
$\Delta h_{R}^{0}($ Kolbe $)$ & $\mathrm{kJ} / \mathrm{mol}$ & 21.7 & 22.6 & 43.3 \\
$w_{\text {el, } \min }$ & $\mathrm{kJ} / \mathrm{mol}$ & 2412.1 & 2412.1 & 2412.1 \\
$\eta_{\text {en, } \text { max }}$ & $\%$ & 27.9 & 54.6 & 75.9 \\
\hline
\end{tabular}

\section{Appendix C}

The effect of pressure on the vapor liquid equilibrium of the binary mixture containing butyl valerate and n-octane is shown in Figure A1. The T-x-y-diagram shows no azeotropes.

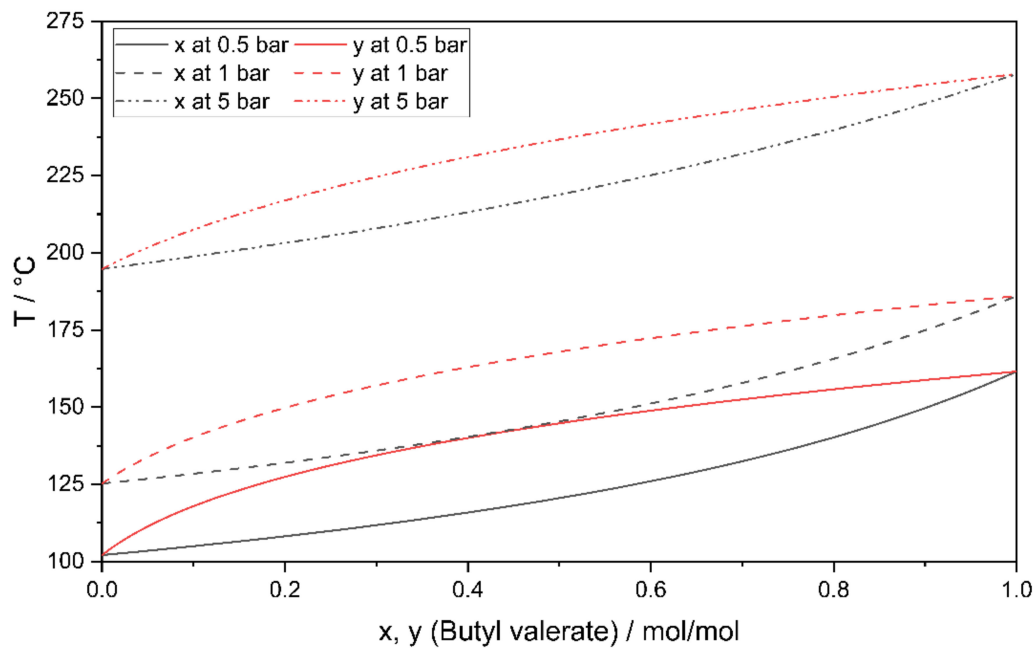

Figure A1. T-x-y-diagram of butyl valerate and n-octane for various pressures. 


\section{References}

1. Hoegh-Guldberg, O.; Jacob, D.; Taylor, M.; Bindi, M.; Brown, S.; Camilloni, I.; Diedhiou, A.; Djalante, R.; Ebi, K.L.; Engelbrecht, F.; et al. Impacts of $1.5^{\circ} \mathrm{C}$ Global Warming on Natural and Human Systems. In Global Warming of $1.5^{\circ} \mathrm{C}$. An IPCC Special Report on the Impacts of Global Warming of $1.5^{\circ} \mathrm{C}$ Above Pre-Industrial Levels and Related Global Greenhouse Gas Emission Pathways, in the Context of Strengthening the Global Response to the Threat of Climate Change, Sustainable Development, and Efforts to Eradicate Poverty; IPCC: Geneva, Switzerland, 2018.

2. Fraunhofer ISE. Net Installed Electricity Generation Capacity in Germany in 2018. Available online: https:/ / energy-charts.info/ charts/installed_power/chart.htm?l=de\&c=DE\&stacking=stacked_percent (accessed on 16 December 2020).

3. Burger, B. Net Public Electricity Generation in Germany in 2018. Available online: https://www.ise.fraunhofer.de/content/dam/ ise/en/documents/News/Stromerzeugung_2018_2_en.pdf (accessed on 16 December 2020).

4. Kolbe, H. Zersetzung der Valeriansäure durch den elektrischen Strom. Ann. Chem. Pharm. 1848, 64, 339-341. [CrossRef]

5. Palkovits, S.; Palkovits, R. The Role of Electrochemistry in Future Dynamic Bio-Refineries: A Focus on (Non-)Kolbe Electrolysis. Chem. Ing. Tech. 2019, 91, 699-706. [CrossRef]

6. Anastas, P.; Eghbali, N. Green chemistry: Principles and practice. Chem. Soc. Rev. 2010, 39, 301-312. [CrossRef] [PubMed]

7. Schäfer, H.-J. Recent contributions of kolbe electrolysis to organic synthesis. In Electrochemistry IV; Steckhan, E., Ed.; Springer: Berlin, Germany, 1990; pp. 91-151. ISBN 3-540-51461-9.

8. Urban, C.; Harnisch, F. Deterioration of Aqueous n- Octanoate Electrolysis with Electrolytic Conductivity Collapse Caused by the Formation of n -Octanoic Acid/ n -Octanoate Agglomerates. Chem. Electro. Chem. 2017, 4, 1378-1389. [CrossRef]

9. Schäfer, H.J. Recent synthetic applications of the Kolbe electrolysis. Chem. Phys. Lipids 1979, 24, 321-333. [CrossRef]

10. Ahad, N.; de Klerk, A. Fischer-Tropsch acid water processing by Kolbe electrolysis. Fuel 2018, 211, 415-419. [CrossRef]

11. dos Santos, T.R.; Harnisch, F.; Nilges, P.; Schröder, U. Electrochemistry for biofuel generation: Transformation of fatty acids and triglycerides to diesel-like olefin/ether mixtures and olefins. ChemSusChem 2015, 8, 886-893. [CrossRef]

12. Meyers, J.; Mensah, J.B.; Holzhäuser, F.J.; Omari, A.; Blesken, C.C.; Tiso, T.; Palkovits, S.; Blank, L.M.; Pischinger, S.; Palkovits, R. Electrochemical conversion of a bio-derivable hydroxy acid to a drop-in oxygenate diesel fuel. Energy Environ. Sci. 2019, 12, 2406-2411. [CrossRef]

13. Holzhäuser, F.J.; Creusen, G.; Moos, G.; Dahmen, M.; König, A.; Artz, J.; Palkovits, S.; Palkovits, R. Electrochemical cross-coupling of biogenic di-acids for sustainable fuel production. Green Chem. 2019, 21, 2334-2344. [CrossRef]

14. Nilges, P.; dos Santos, T.R.; Harnisch, F.; Schröder, U. Electrochemistry for biofuel generation: Electrochemical conversion of levulinic acid to octane. Energy Environ. Sci. 2012, 5, 5231-5235. [CrossRef]

15. Urban, C.; Xu, J.; Sträuber, H.; dos Santos Dantas, T.R.; Mühlenberg, J.; Härtig, C.; Angenent, L.T.; Harnisch, F. Production of drop-in fuels from biomass at high selectivity by combined microbial and electrochemical conversion. Energy Environ. Sci. 2017, 10, 2231-2244. [CrossRef]

16. de Kruijff, G.H.M.; Waldvogel, S.R. Electrochemical Synthesis of Aryl Methoxymethyl Ethers. Chem. Electro. Chem. 2019, 6, 4180-4183. [CrossRef]

17. Wu, L.; Mascal, M.; Farmer, T.J.; Arnaud, S.P.; Wong Chang, M.-A. Electrochemical Coupling of Biomass-Derived Acids: New C8 Platforms for Renewable Polymers and Fuels. ChemSusChem 2017, 10, 166-170. [CrossRef] [PubMed]

18. Zhang, Y.; Liu, G.; Wu, J. Electrochemical conversion of palmitic acid via Kolbe electrolysis for synthesis of n-triacontane. J. Electroanal. Chem. 2018, 822, 73-80. [CrossRef]

19. Ho, C.K.; McAuley, K.B.; Peppley, B.A. Biolubricants through renewable hydrocarbons: A perspective for new opportunities. Renew. Sustain. Energy Rev. 2019, 113, 109261. [CrossRef]

20. Stang, C.; Harnisch, F. The Dilemma of Supporting Electrolytes for Electroorganic Synthesis: A Case Study on Kolbe Electrolysis. ChemSusChem 2016, 9, 50-60. [CrossRef]

21. Ziogas, A.; Hofmann, C.; Baranyai, S.; Löb, P.; Kolb, G. Novel Flexible Electrochemical Microreactor and its Validation by Three Model Electrosyntheses. Chem. Ing. Tech. 2020. [CrossRef]

22. Ziogas, A.; Pennemann, H.; Kolb, G. Electrochemical Synthesis of Tailor-Made Hydrocarbons from Organic Solvent Free Aqueous Fatty Acid Mixtures in a Micro Flow Reactor. Electrocatalysis 2020, 11, 432-442. [CrossRef]

23. Holzhäuser, F.J.; Mensah, J.B.; Palkovits, R. (Non-)Kolbe electrolysis in biomass valorization-A discussion of potential applications. Green Chem. 2020, 22, 286-301. [CrossRef]

24. Kooijman, H.; Taylor, R. ChemSep v8.01 Pure Component Data. 2018. Available online: http:/ /www.chemsep.org/ (accessed on 16 December 2020).

25. Kim, S.; Chen, J.; Cheng, T.; Gindulyte, A.; He, J.; He, S.; Li, Q.; Shoemaker, B.A.; Thiessen, P.A.; Yu, B.; et al. PubChem 2019 update: Improved access to chemical data. Nucleic Acids Res. 2019, 47, D1102-D1109. [CrossRef]

26. Knothe, G.; Dunn, R.O. A Comprehensive Evaluation of the Melting Points of Fatty Acids and Esters Determined by Differential Scanning Calorimetry. J. Am. Oil Chem Soc. 2009, 86, 843-856. [CrossRef]

27. Klopman, G.; Wang, S.; Balthasar, D.M. Estimation of aqueous solubility of organic molecules by the group contribution approach. Application to the study of biodegradation. J. Chem. Inf. Comput. Sci. 1992, 32, 474-482. [CrossRef]

28. Constable, D.J.C.; Curzons, A.D.; Cunningham, V.L. Metrics to 'green' chemistry-Which are the best? Green Chem. 2002, 4, 521-527. [CrossRef]

29. Bell, G.H. Solubilities of normal aliphatic acids, alcohols and alkanes in water. Chem. Phys. Lipids 1973, 10, 1-10. [CrossRef] 
30. Bond, A.D. On the crystal structures and melting point alternation of the n-alkyl carboxylic acids. New J. Chem. 2004, $28,104-114$. [CrossRef]

31. Ogino, K.; Ichikawa, Y. The Solubilities and Kraft Points of Fatty Acid Soaps of Odd Carbon Numbers. BCSJ 1976, 49 , $2683-2686$. [CrossRef]

32. McBain, J.W.; Sierichs, W.C. The solubility of sodium and potassium soaps and the phase diagrams of aqueous potassium soaps. J. Am. Oil Chem. Soc. 1948, 25, 221-225. [CrossRef]

33. Quast, K. The use of zeta potential to investigate the $\mathrm{p} \mathrm{K}$ a of saturated fatty acids. Adv. Powder Technol. 2016, 27, 207-214. [CrossRef]

34. Kanicky, J.R.; Shah, D.O. Effect of degree, type, and position of unsaturation on the pKa of long-chain fatty acids. J. Colloid Interface Sci. 2002, 256, 201-207. [CrossRef]

35. Soontravanich, S.; Lopez, H.E.; Scamehorn, J.F.; Sabatini, D.A.; Scheuing, D.R. Dissolution Study of Salt of Long Chain Fatty Acids (Soap Scum) in Surfactant Solutions. Part I: Equilibrium Dissolution. J. Surfactants Deterg. 2010, 13, 367-372. [CrossRef]

36. Quast, K. Flotation of hematite using C6-C18 saturated fatty acids. Miner. Eng. 2006, 19, 582-597. [CrossRef]

37. Lucassen, J. Hydrolysis and Precipitates in Carboxylate Soap Solutions. J. Phys. Chem. 1966, 70, 1824-1830. [CrossRef]

38. Kralchevsky, P.A.; Danov, K.D.; Pishmanova, C.I.; Kralchevska, S.D.; Christov, N.C.; Ananthapadmanabhan, K.P.; Lips, A. Effect of the precipitation of neutral-soap, acid-soap, and alkanoic acid crystallites on the bulk $\mathrm{pH}$ and surface tension of soap solutions. Langmuir 2007, 23, 3538-3553. [CrossRef] [PubMed]

39. Moroi, Y.; Matuura, R. Relationship between Solubility and Micellization of Surfactants; Micelle Temperature Range (MTR) Instead of Krafft Point. BCSJ 1988, 61, 333-339. [CrossRef]

40. De Mul, M.N.G.; Davis, H.T.; Evans, D.F.; Bhave, A.V.; Wagner, J.R. Solution Phase Behavior and Solid Phase Structure of Long-Chain Sodium Soap Mixtures. Langmuir 2000, 16, 8276-8284. [CrossRef]

41. Klein, R.; Kellermeier, M.; Drechsler, M.; Touraud, D.; Kunz, W. Solubilisation of stearic acid by the organic base choline hydroxide. Colloids Surf. A Physicochem. Eng. Asp. 2009, 338, 129-134. [CrossRef]

42. Klein, R.; Touraud, D.; Kunz, W. Choline carboxylate surfactants: Biocompatible and highly soluble in water. Green Chem. 2008, 10, 433. [CrossRef]

43. Wolfrum, S. Long chain soaps and alkyl sulfates in aqueous solutions at room temperature. Ph.D. Thesis, Universität Regensburg, Regensbug, Germany, 24 October 2018.

44. Lin, B.; McCormick, A.V.; Davis, H.T.; Strey, R. Solubility of sodium soaps in aqueous salt solutions. J. Colloid Interface Sci. 2005, 291, 543-549. [CrossRef]

45. Umemura, J.; Mantsch, H.H.; Cameron, D.G. Micelle formation in aqueous n-alkanoate solutions: A fourier transform infrared study. J. Colloid Interface Sci. 1981, 83, 558-568. [CrossRef]

46. Mukerjee, P.; Mysels, K. Critical Micelle Concentrations of Aqueous Surfactant Systems. 1971. Available online: https: / www.google.com.hk/url?sa=t\&rct=j\&q=\&esrc=s\&source=web\&cd=\&ved=2ahUKEwiptfHFh-TtAhUbIIgKHTW2 BtEQFjABegQIAhAC\&url=https\%3A\%2F\%2Fnvlpubs.nist.gov\%2Fnistpubs\%2FLegacy\%2FNSRDS\%2Fnbsnsrds36.pdf\&usg= AOvVaw2AxOwGeIA2pma58QErkHey (accessed on 16 December 2020).

47. Dickinson, T.; Wynne-Jonnes, W.F.K. Mechanism of Kolbe's electrosynthesis. Part 1-Anode potential phenomena. Trans. Faraday Soc. 1962, 382-387. [CrossRef]

48. Grote, K.-H.; Bender, B.; Gohlich, D. Dubbel Taschenbuch für den Maschinenbau; Grote, K.-H., Bender, B., Göhlich, D., Eds.; Springer: Berlin, Germany, 2018; ISBN 978-3-662-54804-2.

49. Feinstein, M.E.; Rosano, H.L. Influence of micelles on titrations of aqueous sodium and potassium soap solutions. J. Phys. Chem. 1969, 73, 601-607. [CrossRef]

50. Saleeb, F.Z.; Cante, C.J.; Streckfus, T.K.; Frost, J.R.; Rosano, H.L. Surface pH and stability of oil-water emulsions derived from laurate solutions. J. Am. Oil Chem Soc. 1975, 52, 208-212. [CrossRef]

51. dos Santos, T.R.; Nilges, P.; Sauter, W.; Harnisch, F.; Schröder, U. Electrochemistry for the generation of renewable chemicals: Electrochemical conversion of levulinic acid. RSC Adv. 2015, 5, 26634-26643. [CrossRef] 